\title{
PEMBERIAN INOSITOL TERHADAP PENINGKATAN PERTUMBUHAN DAN SINTASAN JUVENIL IKAN GURAMI (Osphronemus gouramy Lac.)
}

\section{INOSITOL SUPPLEMENT ON FISH DIET FOR GROWTH AND SURVIVAL RATE OF JUVENILE GOURAMI (Osphronemus gouramy Lac.)}

\author{
Ayu Nirarai Putri, Endang L. Widiastuti, Nuning Nurcahyani, M. Kanedi \\ Jurusan Biologi FMIPA Universitas Lampung \\ e-mail : niraraiayu@yahoo.com \\ Jurusan Biologi FMIPA Universitas Lampung \\ Jl. Soemantri Brojonegoro No.1, Bandar Lampung, Lampung, Indonesia, 35145
}

\begin{abstract}
Abstrak
Pertumbuhan ikan gurami (Osphronemus gouramy Lac.) sangat lambat, tingkat mortalitasnya juga tinggi akibat serangan penyakit maupun perubahan lingkungan yang tidak menentu. Inositol adalah kelompok poliol karbosiklik yang banyak ditemukan dalam produk makanan yang dikonsumsi manusia yang diketahui dapat membantu dalam peningkatan imunitas tubuh terhadap bakteri patogen. Penelitian ini bertujuan untuk mengetahui pengaruh penambahan inositol pada pakan komersil terhadap peningkatan pertumbuhan dan sintasan juvenil ikan gurami. Penelitian ini dilaksanakan di Gedong Tataan, Kabupaten Pesawaran, Provinsi Lampung pada bulan Desember 2013 - Februari 2014. Penelitian ini menggunakan Rancangan Acak Lengkap (RAL) yang terdiri dari kontrol tanpa penambahan inositol (konsentrasi inositol $0 \mathrm{mg} / 100 \mathrm{~g}$ pakan) dan 2 perlakuan penambahan inositol yaitu konsentrasi $10 \mathrm{mg} / 100 \mathrm{~g}$ pakan, dan $20 \mathrm{mg} / 100 \mathrm{~g}$ pakan. Data diperoleh setiap minggu diantaranya dalam bentuk sintasan, berat tubuh, panjang tubuh, lebar tubuh, rasio otot (MR), indeks hepatosomatik (HSI), indeks visceralsomatik (VSI), dan laju pertumbuhan spesifik. Keseluruhan data dari parameter dianalisis menggunakan Anova dan uji Tukey's $(\alpha=5 \%)$. Hasil penunjukkan bahwa penambahan inositol $10 \mathrm{~g} / 100 \mathrm{~g}$ pakan menunjukkan tingkat kelulushidupan yang tertinggi, mencapai $99,5 \%$, serta meningkatkan pertambahan berat tumbuh secara nyata $(p \leq 0.05)$ dibandingkan kontrol. Peningkatan ini diikuti dengan peningkatan panjang tubuh. Namun semua nilai indeks (HSI, VSI, MR) tidak menunjukkan perbedaan yang nyata.
\end{abstract}

Katakunci: Juvenil Gurami, Inositol, pertumbuhan, sintasan.

\begin{abstract}
Gouramy (Osphronemus gouramy Lac.) has slow growth rate and high mortality caused by disease. Meanwhile, Inositol is known as carbocyclic polyol which known to increase the immunity againt pathogenic bacteria in human. This study was conducted to elucide any possibility effect of inositol in diet on improving and surviving rate of juvenil gouramy. The study was conducted in outdoor fish pond in Gedong Tataan - Pesawaran - Lampung Province from December 2013 - February 2014 by using 75 juvenile gouramy with average body weight of $30-50 \mathrm{~g}$. The fishes was divided into 3 different groups, one was control group receiving only fish diet, one group receiving $10 \mathrm{mg}$ inositol/100 g fish diet, and other receiving $20 \mathrm{mg}$ inositol $/ 100 \mathrm{~g}$ fish diet. Complete randomly design was assigned for this study. Data were collected for every week included the survival rate, body weight, length, and width, muscle ratio, hepatosomatic index, vicerosomatic index, specific growth rate and analyzed with ANOVA followed with Tukey's. The result indicated that inositol $10 \mathrm{~g} / 100 \mathrm{~g}$ diet had highest survival rate reaching to $99.5 \%$ and also increased the body weight significantly $(p \leq 0.05)$ compared to control and this followed by increased in body length. However all the indexes showed no significantly differences.
\end{abstract}

Keywords: Juvenile gouramy, inositol, growth, survival rate.

\section{PENDAHULUAN}

Kendala pada masa pembenihan dan pendederan dalam usaha budidaya ikan gurami (Osphronemus gouramy Lac.) paling sering terjadi (Effendi, 2006). Pertumbuhan ikan gurami (Os- phronemus gouramy Lac.) sangat lambat jika dibandingkan dengan ikan air tawar lainnya. Selain itu, jika sistem imun ikan kurang memadai akibat tekanan lingkungan yang tinggi pada masa pertumbuhan maka mortalitas gurami (Osphronemus gouramy Lac.) akan meningkat 
dan menimbulkan kerugian bagi para pembudidaya ikan gurami (Osphronemus gouramy Lac.). Inositol berupa myo-inositol di dalam tubuh merupakan nutrisi alami yang tersusun atas isomer gula alkohol dengan rantai $\mathrm{C} 6$ dan termasuk dalam kelompok vitamin B-kompleks yang berperan penting sebagai dasar struktural (Kane, 1988), nutrisi essensial yang penting untuk sebagian besar hewan air (Michael dan Koshio, 2008), jalur sinyal transduksi yang dikontrol oleh hormon tertentu, neurotransmitter, atau berperan sebagai faktor pertumbuhan (Shiau dan Yu, 2006). Tujuan dari penelitian ini adalah untuk mengetahui pengaruh penambahan inositol pada pakan komersil terhadap peningkatan

\section{BAHAN DAN METODE PENELITIAN}

Penelitian ini akan dilaksanakan pada bulan Desember 2013 - Februari 2014 di Desa Way Linti, Kelurahan Wiyono, Kecamatan Gedong Tataan, Kabupaten Pesawaran, Provinsi Lampung. Bahan dan alat yang digunakan dalam penelitian ini terdiri dari: 75 ekor juvenil gurami (Oshpronemus gouramy Lac.) yang berumur 4-5 bulan dengan berat tubuh $30-50 \mathrm{~g}$, kolam buatan di lahan terbuka (outdoor), 3 buah waring berukuran 1,7 $\mathrm{m} \times 0,6$ $\mathrm{m} \times 2 \mathrm{~m}$, myo-inositol (C6H12O6) dari Merck ${ }^{\circ}$, pellet komersil, neraca ohauss kapasitas $310 \mathrm{~g}$, neraca digital Orion model 862, jaring, bak, mistar, botol semprot, pisau, gunting, pinset, alat-alat tulis, $\mathrm{pH}$ indikator strip $\mathrm{KGaA}$ dari Merck ${ }^{\circledR}$, termometer air raksa $100^{\circ} \mathrm{C}, \mathrm{NO} 2$ tes kit dari Sera, DO meter probe digital, dan minyak cengkeh sebagai anastesi bagi ikan. Penelitian ini menggunakan Rancangan Acak Lengkap (RAL) yang terdiri dari kontrol tanpa penambahan inositol (konsentrasi $0 \mathrm{mg} / 100 \mathrm{~g}$ pakan) dan 2 perlakuan penambahan inositol yaitu konsentrasi $10 \mathrm{mg} / 100 \mathrm{~g}$ pakan, dan 20 $\mathrm{mg} / 100 \mathrm{~g}$ pakan, masing-masing kelompok perlakuan terdiri atas 25 ekor ikan dengan pengulangan sebanyak 3 kali. Ikan diberi makan sebanyak $5 \%$ dari berat biomassa ikan dengan frekuensi pemberian pakan 2 kali pada pagi dan sore hari.

Pengambilan data berupa berat tubuh, panjang tubuh, lebar tubuh, berat hepar, berat visceral, dan berat otot dilakukan setiap 7 hari sekali selama 8 minggu untuk dikonversikan menjadi rerata berat, rerata panjang, rerata lebar, indeks hepatosomatik (HSI), indeks visceral-somatik (VSI), rasio otot (MR), dan laju pertumbuhan spesifik (SGR). Selama penelitian ikan yang mati dicatat jumlahnya dan ditimbang beratnya guna perhitungan sintasan / kelulushidupan (SR). Jumlah pakan yang dihabiskan juga dicatat setiap hari guna perhitungan rasio konversi pakan (FCR). Pengambilan data kualitas air dilakukan setiap 7 hari sekali selama 8 minggu. Keseluruhan parameter uji dianalisis secara statistik menggunakan Anova pada taraf signifikansi $(\alpha)$ $5 \%$ dan dilakukan uji lanjut menggunakan Uji Beda Nyata Terkecil atau Tuckey's multiple comparison test pada taraf signifikansi (a) $5 \%$ apabila terdapat perbedaan yang nyata antar perlakuan, sedangkan data kualitas air akan dianalisis secara deskriptif.

\subsection{Persiapan Pakan}

Pakan uji yang digunakan dalam penelitian ini adalah pellet komersil yang diberi penambahan inositol dengan konsentrasi yang telah ditentukan dengan cara melakukan konversi dosis penggunaan inositol pada manusia dewasa untuk ikan dengan berat 30$50 \mathrm{~g}$. Inositol dengan masing-masing konsentrasi dilarutkan ke dalam aquades, kemudian disemprotkan pada pakan sesuai dengan konsentrasi yang telah ditentukan sebelumnya $(0 \mathrm{mg} / 100 \mathrm{~g}$ pakan, $10 \mathrm{mg} / 100 \mathrm{~g}$ pakan, dan $20 \mathrm{mg} / 100 \mathrm{~g}$ pakan). Selanjutnya, pakan dikeringanginkan dan disimpan padai wadah yang tertutup rapat agar kualitasnya tetap terjaga dengan baik.

\section{HASIL DAN PEMBAHASAN}

Pada Gambar 1, berdasarkan analisis statistik menggunakan Anova pada taraf signifikansi (a) $5 \%$ dan uji lanjut Tuckey's multiple comparison test pada taraf signifikansi yang sama, secara umum diketahui bahwa rata-rata pertambahan berat tubuh juvenil gurami (Osphronemus gouramy Lac.) pada kontrol dan 2 perlakuan penambahan inositol yaitu konsentrasi $10 \mathrm{mg} / 100 \mathrm{~g}$ pakan dan konsentrasi $20 \mathrm{mg} / 100 \mathrm{~g}$ pakan per waktu pengukuran tidak menghasilkan perbedaan yang nyata antar perlakuan. Namun, pada kelompok perlakuan penambahan inositol 10 $\mathrm{mg} / 100 \mathrm{~g}$ pakan diketahui dapat meningkatkan pertambahan beratnya bila dibandingkan dengan 2 kelompok perlakuan lainnya, dengan rata-rata pertambahan berat tertinggi terjadi pada hari ke-56 sebesar 27,90 g. Myo-inositol merupakan komponen dari membran sel, yang juga berperan sebagai nutrisi essensial yang dibutuhkan oleh sel manusia untuk pertumbuhan dan berkembang biak. 


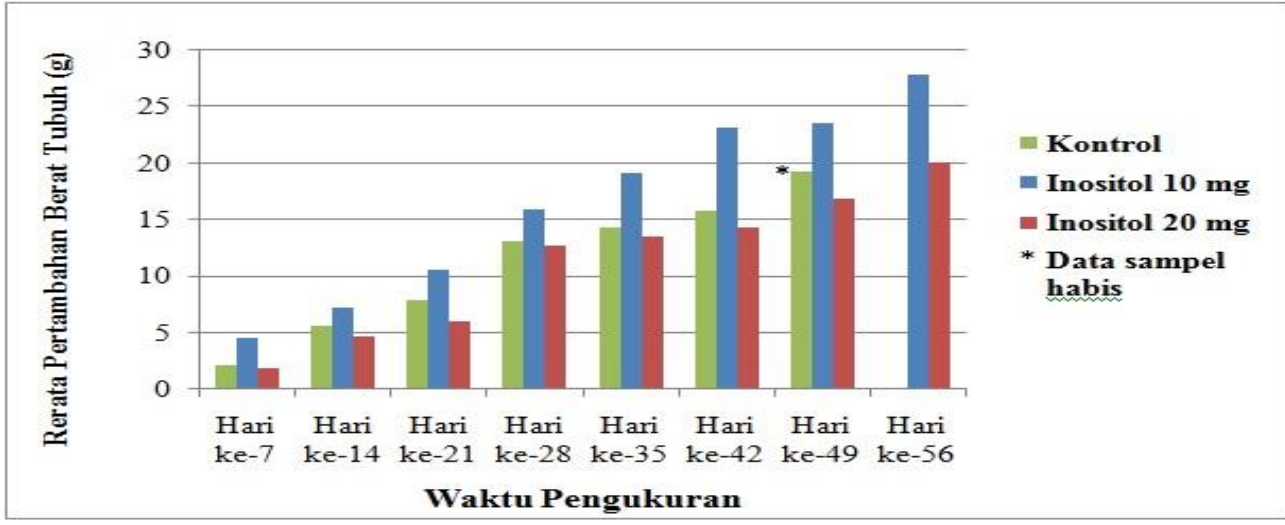

Gambar 1. Rerata Pertambahan Berat Tubuh Juvenil Ikan Gurami (Osphronemus gouramy Lac.) (g) selama 8 Minggu.

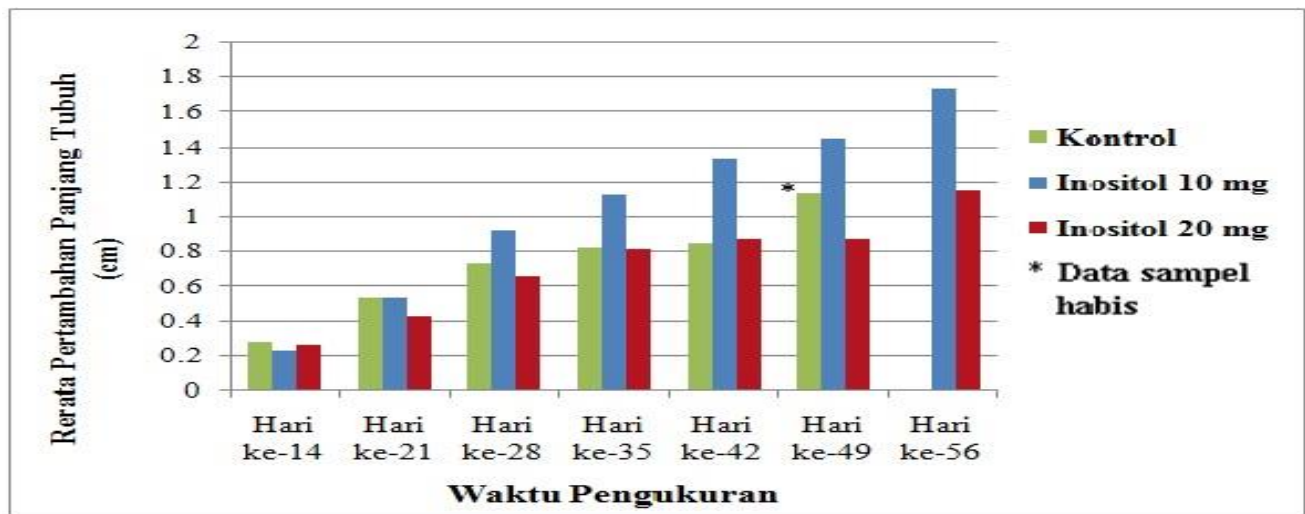

Gambar 2. Rerata Pertambahan Panjang Tubuh Juvenil Ikan Gurami (Osphronemus gouramy Lac.) (cm) selama 8 Minggu.

Pada Gambar 2 menunjukkan bahwa rata-rata pertambahan berat panjang juvenil gurami (Osphronemus gouramy Lac.) pada kontrol dan 2 perlakuan penambahan inositol yaitu konsentrasi $10 \mathrm{mg} / 100 \mathrm{~g}$ pakan dan konsentrasi 20 $\mathrm{mg} / 100 \mathrm{~g}$ pakan per waktu pengukuran tidak berbeda nyata, namun mengalami kenaikan pada masing-masing kelompok perlakuan dengan kenaikan tertinggi diperoleh oleh kelompok perlakuan penambahan inositol $10 \mathrm{mg} / 100$ g pakan sebesar $1,73 \mathrm{~cm}$ pada pengukuran hari ke-56. Jika melihat hubungan antara pertambahan panjang dan berat tubuhnya (Gambar 1 dan 2) diketahui bahwa berat dan panjang memberikan hubungan yang berlawanan, dimana saat berat tubuh juvenil ikan gurami (Osphronemus gouramy Lac.) meningkat maka proses pemanjangan tubuh akan melambat, begitu pula sebaliknya.

Pada Gambar 3 pengukuran pertambahan lebar tubuh juvenil gurami (Osphronemus gouramy Lac.) menunjukkan hasil yang tidak berbeda nyata. Pertambahan lebar tubuh ikan gurami (Osphronemus gouramy Lac.) pada perlakuan penambahan inositol $10 \mathrm{mg} / 100 \mathrm{~g}$ pakan lebih tinggi bila dibandingkan dengan perlakuan kontrol dan perlakuan penambahan inositol $20 \mathrm{mg} / 100 \mathrm{~g}$ pakan. Dapat diduga bahwa senyawa inositol memberikan efek pertumbuhan pada pelebaran tubuh juvenil ikan gurami (Osphronemus gouramy Lac.). Hal ini sesuai dengan pendapat jika terdapat kelebihan energi, maka energi akan akan disimpan dan digunakan untuk pertumbuhan (Yandest, dkk., 2003).

Tabel 1. Tingkat Kelulushidupan (SR) Juvenil Gurami (Osphronemus gouramy Lac.) selama 8 Minggu.

\begin{tabular}{cc}
\hline Perlakuan & $\begin{array}{c}\text { Tingkat Kelulushidupan } \\
\text { (Rerata } \pm \text { SEM) (\%) }\end{array}$ \\
\hline Kontrol & $89,33 \pm 5,58$ \\
Inositol $10 \mathrm{mg}$ & $99,50 \pm 0,50$ \\
Inositol $20 \mathrm{mg}$ & $94,27 \pm 4,23$ \\
\hline
\end{tabular}

Keterangan: $\bar{X} \pm$ SEM: Nilai rata-rata kelulushidupan \pm galat baku

Tingkat kelulushidupan juvenil gurami (Osphronemus gouramy Lac.) pada penelitian ini diketahui tidak mencapai $100 \%$ pada akhir penelitian (Tabel 1), tetapi menunjukkan hasil yang lebih besar pada kedua kelompok perlakuan (inositol $10 \mathrm{mg} / 100 \mathrm{~g}$ pakan dan inositol 20 
$\mathrm{mg} / 100 \mathrm{~g}$ pakan) bila dibandingkan dengan perlakuan pada kelompok kontrol, dengan kelulushidupan tertinggi diperoleh pada perlakuan pemberian inositol $10 \mathrm{mg} / 100 \mathrm{~g}$ pakan sebesar $99,50 \%$. Diduga bahwa kondisi lingkungan pada masa penelitian kurang baik sehingga terjadi kematian meski jumlah kebutuhan pakan yang diberikan sebanyak $5 \%$ dari berat tubuh per hari dengan interval pemberian pakan sebanyak 2 kali telah mencukupi kebutuhan juvenil ikan gurami (Osphronemus gouramy Lac.) untuk bertahan hidup dan tumbuh.

Pada Tabel 2 diketahui bahwa indeks hepatosomatik juvenil ikan gurami (Osphronemus gouramy Lac.) pada kontrol dan 2 perlakuan penambahan inositol yaitu konsentrasi $10 \mathrm{mg} / 100$ $\mathrm{g}$ pakan dan konsentrasi $20 \mathrm{mg} / 100 \mathrm{~g}$ pakan per waktu pengukuran tidak berbeda nyata. Menurut Sulistyo dkk. dalam Heltonika (Heltonika, 2009), Indeks hepatosomatik yang tinggi dapat mengindikasikan keadaan komposisi dari tubuh dan laju pertumbuhan pada ikan khususnya dalam kinerja reproduksi. Pada penelitian ini rendahnya indeks hepatosomatik diduga karena juvenil ikan gurami masih membutuhkan banyak energi untuk proses pertumbuhan jaringan somatik sehingga kelebihan sisa energi akan digunakan dalam sintesis protein untuk pertumbuhan daripada ditimbun sebagai lemak dalam otot, hati, dan organ visceral.

Indeks visceral-somatik (VSI) juvenil ikan gurami (Osphronemus gouramy Lac.) (Tabel 3) pada kontrol dan 2 perlakuan penambahan inositol per waktu pengukuran secara umum tidak menghasilkan perbedaan yang nyata antar perlakuan, kecuali pada pengukuran hari ke-28. Dapat dilihat bahwa kenaikan rata-rata indeks visceral-somatik hanya terjadi pada pengukuran hari ke-14 pada. Rendahnya nilai indeks visceral-somatik (VSI) diduga karena juvenil ikan gurami (Osphronemus gouramy Lac.) masih membutuhkan banyak energi untuk pertumbuhan dan bertahan hidup terhadap perubahan lingkungan sehingga tingkat pembentukan lemak menjadi rendah. Hal ini sesuai dengan pernyataan bahwa semua simpanan energi di dalam tubuh akan dikerahkan secara massal saat kebutuhan ikan terhadap energi cukup besar, sehingga menurunkan nilai otot, indeks hepatosomatik (HSI), dan indek visceral-somatik (VSI) (Heltonika, 2009).

Tabel 2. Nilai Rata-Rata Indeks Hepatosomatik (HSI) Juvenil Gurami (Osphronemus gouramy Lac.) selama 8 Minggu.

\begin{tabular}{cccc}
\hline \multirow{2}{*}{$\begin{array}{c}\text { Waktu } \\
\text { Pengukuran }\end{array}$} & \multicolumn{3}{c}{$\begin{array}{c}\text { Indeks Hepatosomatik } \\
\text { (Rerata HSI } \pm \text { SEM) }\end{array}$} \\
\cline { 2 - 4 } & Kontrol & $\begin{array}{c}\text { Inositol 10 } \\
\text { mg }\end{array}$ & $\begin{array}{c}\text { Inositol 20 } \\
\text { mg }\end{array}$ \\
\hline Hari ke-7 & $1,89 \pm 0,31$ & $1,50 \pm 0,47$ & $2,04 \pm 0,21$ \\
Hari ke-14 & $4,13 \pm 0,66$ & $4,26 \pm 0,37$ & $3,74 \pm 0,13$ \\
Hari ke-21 & $1,84 \pm 0,04$ & $1,56 \pm 0,02$ & $1,94 \pm 0,22$ \\
Hari ke-28 & $1,44 \pm 0,22$ & $1,47 \pm 0,18$ & $1,38 \pm 0,44$ \\
Hari ke-35 & $1,43 \pm 0,07$ & $1,28 \pm 0,18$ & $1,74 \pm 0,24$ \\
Hari ke-42 & $1,17 \pm 0,12$ & $1,53 \pm 0,17$ & $1,09 \pm 0,03$ \\
Hari ke-49 & $1,22 \pm 0,19$ & $1,28 \pm 0,07$ & $1,36 \pm 0,14$ \\
Hari ke-56 & - & $1,10 \pm 0,14$ & $1,21 \pm 0,07$ \\
\hline
\end{tabular}

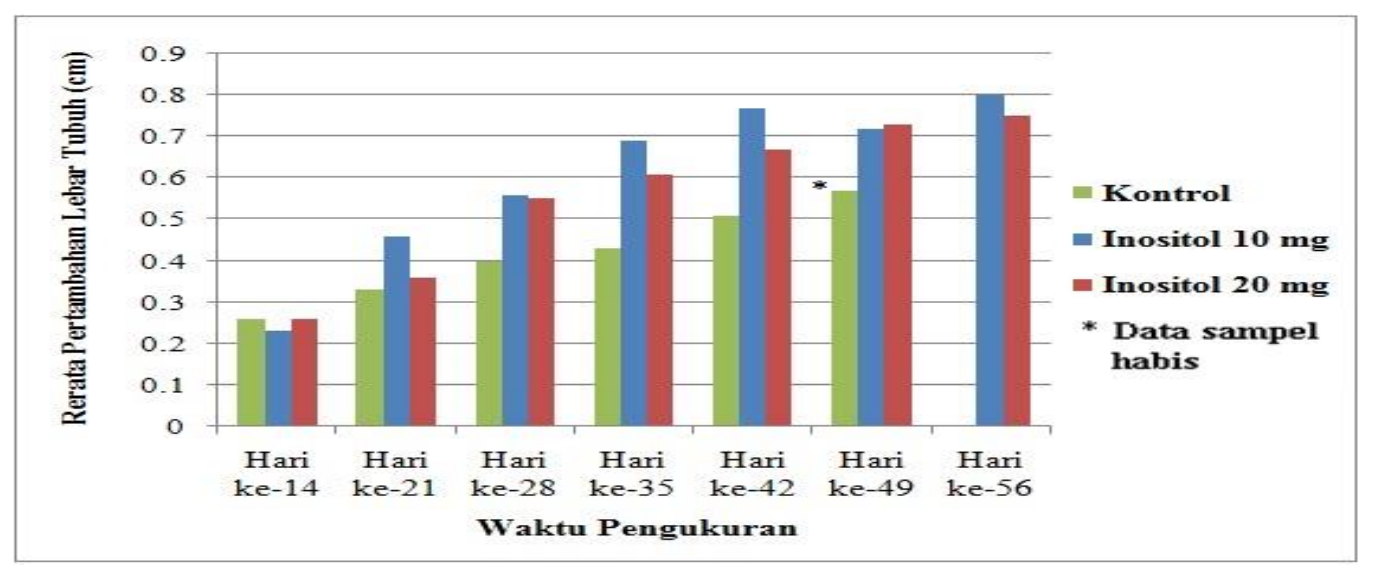

Gambar 3 Rerata Pertambahan Lebar Tubuh Juvenil Ikan Gurami (Osphronemus gouramy Lac.) (cm) selama 8 Minggu. 
Tabel 3. Nilai Rata-Rata Indeks Visceral So-matik (VSI) Juvenil Gurami (Osphro-nemus gouramy Lac.) selama 8 Ming-gu.

\begin{tabular}{cccc}
\hline Waktu & \multicolumn{3}{c}{ Indeks Visceral Somatik (Rerata VSI \pm SEM) (\%) } \\
\cline { 2 - 4 } Pengukuran & Kontrol & Inositol 10 $\mathbf{~ m g}$ & Inositol 20 $\mathbf{~ g ~}$ \\
\hline Hari ke-7 & $8,19 \pm 1,24$ & $7,47 \pm 1,15$ & $8,94 \pm 1,25$ \\
Hari ke-14 & $9,42 \pm 0,44$ & $10,28 \pm 0,60$ & $10,06 \pm 0,54$ \\
Hari ke-21 & $7,84 \pm 0,48$ & $7,82 \pm 0,45$ & $7,01 \pm 0,43$ \\
Hari ke-28 & $7,37 \pm 0,25 \mathrm{a}$ & $8,44 \pm 0,32 \mathrm{ab}$ & $6,46 \pm 0,66 \mathrm{ac}$ \\
Hari ke-35 & $6,84 \pm 0,31$ & $7,32 \pm 0,04$ & $7,08 \pm 0,85$ \\
Hari ke-42 & $5,64 \pm 0,43$ & $7,42 \pm 0,59$ & $6,67 \pm 0,28$ \\
Hari ke-49 & $6,28 \pm 0,86$ & $6,41 \pm 0,60$ & $6,13 \pm 0,43$ \\
Hari ke-56 & - & $6,87 \pm 0,49$ & $7,69 \pm 0,37$
\end{tabular}

Keterangan : a, b, c : Pengguaan huruf subscribe menandakan adaya perbedaan yang nyata antar data pada taraf signifikansi (a) $5 \%$

Tabel 4 Nilai Rata-Rata Ratio Otot (MR) Juvenil Gurami (Osphronemus gouramy Lac.) selama 8 Minggu.

\begin{tabular}{cccc}
\hline Waktu & \multicolumn{3}{c}{ Ratio Otot (Rerata MR \pm SEM) (\%) } \\
\cline { 2 - 4 } Pengukuran & Kontrol & Inositol 10 $\mathbf{~ g}$ & Inositol 20 $\mathbf{~ m ~}$ \\
\hline Hari ke-7 & $41,66 \pm 16,27$ & $37,59 \pm 3,29$ & $39,06 \pm 3,10$ \\
Hari ke-14 & $46,55 \pm 0,73 \mathrm{a}$ & $45,18 \pm 1,05 \mathrm{~b}$ & $39,74 \pm 1,36 \mathrm{ab}$ \\
Hari ke-21 & $43,75 \pm 0,30$ & $42,48 \pm 0,92$ & $43,25 \pm 0,92$ \\
Hari ke-28 & $44,44 \pm 0,76$ & $43,81 \pm 0,79$ & $40,48 \pm 4,71$ \\
Hari ke-35 & $45,57 \pm 1,56$ & $48,21 \pm 1,15$ & $47,24 \pm 0,61$ \\
Hari ke-42 & $43,38 \pm 2,64$ & $48,17 \pm 1,13$ & $44,56 \pm 0,36$ \\
Hari ke-49 & $47,87 \pm 0,84$ & $47,78 \pm 0,58$ & $48,82 \pm 0,48$ \\
Hari ke-56 & - & $46,12 \pm 3,44$ & $44,83 \pm 0,53$
\end{tabular}

Keterangan : a, b, c : Pengguaan huruf subscribe menandakan adaya perbedaan yang nyata antar data pada taraf signifikansi (a) $5 \%$

Tabel 4 secara umum menunjukkan rasio otot (MR) juvenil ikan gurami (Osphronemus gouramy Lac.) yang tidak berbeda nyata. Jika diperhatikan, dapat dilihat bahwa rata-rata rasio otot (MR) tertinggi terjadi pada pengukuran hari ke-49 pada kelompok penambahan inositol 20 $\mathrm{mg} / 100 \mathrm{~g}$ pakan sebesar $48,82 \%$, diikuti oleh kelompok kontrol sebesar $47,87 \%$ dan kelompok penambahan inositol $10 \mathrm{mg} / 100 \mathrm{~g}$ pakan sebesar $47,78 \%$. Tingginya rasio otot (MR) pada hari ke-49 diduga karena ikan mengalami metabolisme yang lebih efektif sehingga kelebihan sisa energi dapat disimpan dalam jaringan somatik. Hal ini sesuai dengan pendapat jika jumlah total dalam enegi pakan tinggi maka protein di dalam tubuh tidak akan terdegradasi, sehingga sumber energi cadangan tetap berada pada tahap yang optimal (Lovell, 1989).
Rerata laju pertumbuhan spesifik (SGR) juvenil gurami (Osphronemus gouramy Lac.) tidak berbeda nyata antara kelompok perlakuan Pada Gambar 4, populasi juvenil gurami (Osphronemus gouramy Lac.) yang diberi perlakuan penambahan inositol baik pada pemberian inositol $10 \mathrm{mg} / 100 \mathrm{~g}$ pakan maupun $20 \mathrm{mg} / 100 \mathrm{~g}$ pakan secara umum memperlihatkan rata-rata laju pertumbuhan yang lebih tinggi bila dibandingkan dengan kontrol, meskipun pada hari ke-28 kedua perlakuan penambahan inositol menperlihatkan hasil yang lebih rendah. Dapat diduga bahwa inositol berperan dalam mempercepat pertumbuhan dan pemberian inositol 10 $\mathrm{mg} / 100 \mathrm{~g}$ pakan memberikan kontribusi yang baik dalam hal memperkaya kandungan nutrisi pakan yang diberikan pada juvenil gurami (Osphronemus gouramy Lac.). 


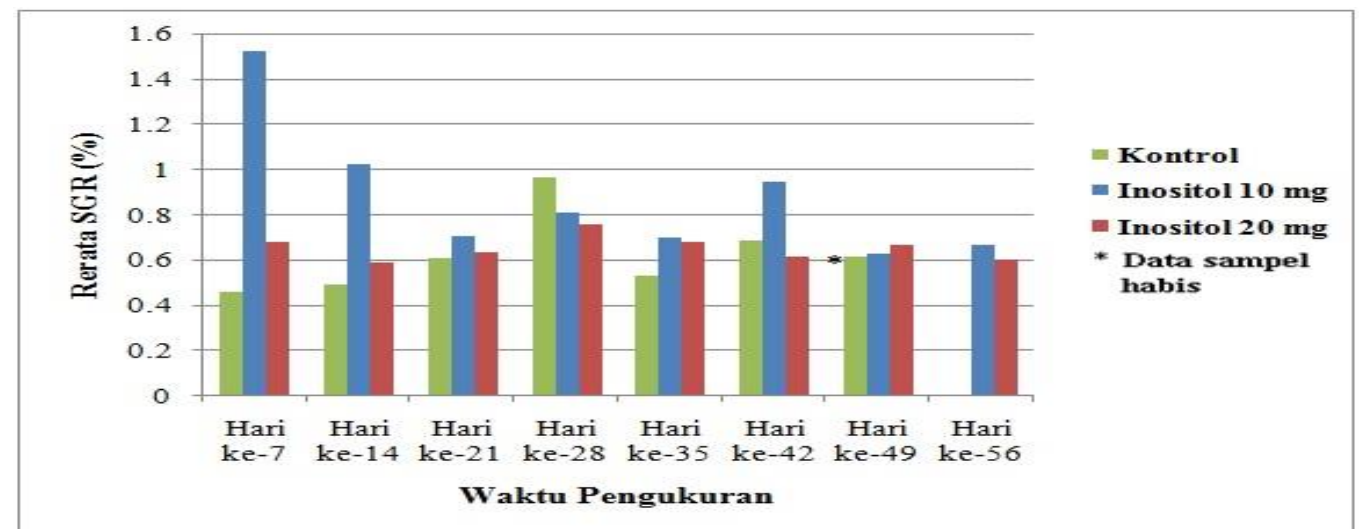

Gambar 4. Rerata Laju Pertumbuhan Spesifik Juvenil Gurami (Osphronemus gouramy Lac.) (\%) selama 8 Minggu.

Pada penelitian ini, rata-rata ratio konversi pakan juga tidak berbeda nyata antar perlakuan. Namun, penambahan inositol dapat menurunkan penggunaan pakan untuk menaikkan $1 \mathrm{~g}$ bobot tubuh juvenil ikan gurami (Osphronemus gouramy Lac.) jika dibandingkan dengan kelompok kontrol (Tabel 5). Dapat diduga bahwa penambahan inositol meningkatkan kualitas dari pakan yang digunakan. Jumlah rerata ratio konversi pakan (FCR) terendah diperoleh oleh perlakuan pemberian inositol $20 \mathrm{mg} / 100 \mathrm{~g}$ pakan dengan perbandingan 1:0,39, dengan kata lain untuk menaikkan $1 \mathrm{~g}$ berat tubuh ikan diperlukan pakan sebanyak $0,39 \mathrm{~g}$. Hal ini menunjukkan bahwa kualitas pakan dengan penambahan inositol $20 \mathrm{mg}$ semakin baik, sehingga mampu menaikkan berat tertentu dengan jumlah penggunaan pakan yang sedikit dan lebih efisien. Hal ini sesuai dengan pendapat Hariati (Hariati, 1989) nilai perhitungan konversi pakan terendah mengisyaratkan bahwa tingkat efisiensi penggunaan pakan berada dalam kondisi kualitas pakan lebih baik dari perlakuan yang lain. Kondisi kualitas pakan yang baik mengakibatkan energi yang diperoleh juvenil ikan gurami (Osphronemus gouramy Lac.) lebih banyak digunakan untuk pertumbuhan.

Tabel 5. Rata-Rata Ratio Konversi Pakan (FCR) Juvenil Gurami (Osphronemus gouramy Lac.) selama 8 Minggu.

\begin{tabular}{cc}
\hline Perlakuan & $\begin{array}{c}\text { Ratio Konversi Pakan (rerata } \\
\pm \text { SEM) }\end{array}$ \\
\hline Kontrol & $3,54 \pm 3,08$ \\
Inositol $10 \mathrm{mg}$ & $0,52 \pm 0,26$ \\
Inositol $20 \mathrm{mg}$ & $0,39 \pm 0,13$ \\
\hline
\end{tabular}

Pengukuran parameter kualitas air pada kolam buatan yang digunakan selama penelitian secara umum menunjukkan keadaan lingkungan yang baik bagi kehidupan juvenil ikan gurami (Osphronemus gouramy Lac.). Hal ini sesuai dengan Sintanggang dan Sarwono (2005) yang menyatakan bahwa ikan gurami dapat hidup dengan baik pada kondisi lingkungan dengan rentang suhu 24-28 oC, derajat keasaman $(\mathrm{pH})$ $6,5-8$, dan kandungan oksigen terlarut yang berkisar antara 4-6 $\mathrm{mg} / \mathrm{L}$.

\section{Tabel 6 Parameter Kualitas Fisika-Kimia Air}

\begin{tabular}{cccccccccc}
\hline \multirow{2}{*}{ Parameter } & \multicolumn{10}{c}{ Waktu Pengukuran Hari Ke- } \\
\cline { 2 - 11 } & $\mathbf{0}$ & $\mathbf{7}$ & $\mathbf{1 4}$ & $\mathbf{2 1}$ & $\mathbf{2 8}$ & $\mathbf{3 5}$ & $\mathbf{4 2}$ & $\mathbf{4 9}$ & $\mathbf{5 6}$ \\
\hline DO (mg/L) & 1,34 & 1,64 & 1,51 & 2,67 & 2,14 & 2,62 & 2,69 & 4,27 & 8,29 \\
Suhu (oC) & 27,5 & 27,5 & 26 & 25 & 26 & 24,5 & 27 & 25,5 & 27,5 \\
pH & 6 & 6 & 6 & 6 & 6 & 6 & 6 & 6 & 6 \\
NO3 (mg/L) & 0 & 10 & 0 & 0 & 0 & 0 & 0 & 0 & 0 \\
\hline
\end{tabular}

\section{KESIMPULAN}

Penambahan inositol pada pakan komersil mampu meningkatkan pertumbuhan dengan menujukkan adanya pertambahan berat, pertambahan panjang, dan pertambahan lebar tubuh pada juvenil gurami (Osphronemus gouramy Lac.) serta peningkatan kelulushidupan, dengan kinerja penambahan inositol $10 \mathrm{mg} / 100$ $\mathrm{g}$ pakan yang lebih baik bila dibandingkan dengan kelompok lainnya. Penambahan inositol pada pakan tidak menunjukan pengaruh yang nyata pada indeks hepatosomatik, indeks visceral somatik, dan rasio otot dari juvenil gurami (Osphronemus gouramy Lac.). 


\section{UCAPAN TERIMA KASIH}

Penulis menyampaikan terima kasih kepada Direktorat Jendral Pendidikan Tinggi (Dirjen DIKTI) yang telah membiayai penelitian ini melalui Proyek Hibah Bersaing Tahun Anggaran 2013/2014.

\section{DAFTAR PUSTAKA}

Effendi, I., H.J. Bugri, dan Widanarni. 2006. Pengaruh Padat Penebaran terhadap Kelangsungan Hidup dan Pertumbuhan Benih Ikan Gurami Osphronemus gouramy Lac. Ukuran $2 \mathrm{Cm}$. Institut Pertanian Bogor. Bogor. Jurnal Akuakultur Indonesia 5(2):127-135.

Kane, M. T. 1988. The effects of water soluble vitamins on the expansion of rabbit blastocysts. Jurnal Exp. Zool. 245:220-223.

Michael, F. R. dan S. Koshio. 2008. Biochemical Studies on The Interactive Effects of Dietary Choline and Inositol in Juvenile Kuruma Shrimp, Marsupenaeus japonicus Bate. Aquaculture 285:179-183.
Shiau, S. Y. dan H. L. Yu. 2006. Vitamin Requirements of Tilapia : A Review. Aquaculture Nutritions International Symposium 8:129-138.

Yandest, Z., A. Ridwan dan M. Ing, 2003. Pengaruh Pemberian Selulosa dalam Pakan Terhadap Kondisi Biologis Benih Ikan Gurami (Osphronemus gourami Lac.). Jurnal Iktiologi Indonesia 3(I):27-33.

Heltonika, B. 2009. Kajian Makanan dan Kaitannya dengan Reproduksi Ikan Senggaringan (Mystus nigriceps) di Sungai Klawing Purbalingga Jawa Tengah. Thesis. Sekolah Pascasarjana Institut Pertanian Bogor. Bogor.

Lovell, T. 1989. Nutrition and Feeding Fish. AVI Book. Van Nostrannd Reinold. New York. Hal 11-91.

Hariati, A.M. 1989. Makanan Ikan. LUW/UNIBRAW/Fish Fisheries Project. Malang. 99 hlm.

Sitanggang, M. dan B. Sarwono. 2005. Budidaya Gurami (edisi revisi ke 7). Penebar Swadaya. Jakarta. 